\title{
Seasonal variation of microalgal assemblages at a fixed station in King George Island, Antarctica, 1996
}

\author{
Jae-Shin Kang ${ }^{1, *}$, Sung-Ho Kang ${ }^{1}$, Jin Hwan Lee ${ }^{2}$, SangHoon Lee ${ }^{1}$ \\ ${ }^{1}$ Polar Sciences Laboratory, Korea Ocean Research \& Development Institute (KORDI), \\ Ansan PO Box 29, Seoul 425-600, Korea \\ ${ }^{2}$ Department of Biology, Sangmyung University, Seoul 110-743, Korea
}

\begin{abstract}
Microalgal assemblages were measured daily from January to December 1996 at a fixed neritic station in Marian Cove, King George Island, Antarctica. The abundance of microalgae and carbon biomass exhibited clear seasonal variation. Annual mean of total microalgal abundance in

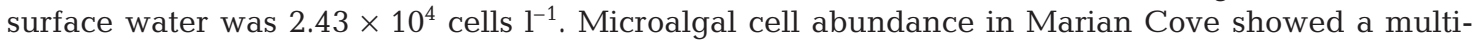
modal distribution of standing crop during the study period. Microalgae started to bloom in October and increased abruptly during November. More than $45 \%$ (avg. $3.5 \mathrm{mg} \mathrm{m}^{-3}$ ) of chl a was present in the 2 months November and December, dominated by microplanktonic diatoms ( $>20 \mu \mathrm{m})$ such as Fragilaria striatula Lyngbye, Licmophora belgicae Peragallo, and Achnanthes groenlandica Grunow. The increase of these diatoms were mainly due to resuspension of benthic microalgae by wind and tidal currents in spring and summer. In contrast, microalgal assemblages in winter were characterized by the dominance of pico- and nanoplanktonic microalgae $(<20 \mu \mathrm{m})$ such as Phaeocystis antarctica Karsten, Navicula glaciei Van Heurck, and Navicula perminuta Grunow.
\end{abstract}

KEY WORDS: Microalgal abundance - Carbon biomass · Diatom · Picoplanktonic microalgae • Nanoplanktonic microalgae $\cdot$ Marian Cove $\cdot$ King George Island

\section{INTRODUCTION}

Microalgae in Antarctic coastal environments have been studied mainly during austral summers (e.g. Dayton et al. 1986, Perrin et al. 1987, Brandini \& Rebello 1994), because micro- and nanoplanktonic microalgal assemblages change considerably during austral summer. The changes are probably a cause of influences such as local wind and tide (Brandini \& Rebello 1994). Although changes of microalgal assemblages in Antarctic coastal environments occur during all 4 seasons, seasonal studies at the species level, such as species abundance, species composition, and succession of phytoplankton in coastal regions, are practically nonexistent (Horne et al. 1969, Krebs 1983). Most studies

\footnotetext{
*E-mail: jskang@kordi.re.kr
}

have analyzed chlorophyll a (chl a) concentration, because analysis at the species level requires a long time period, and taxonomy of neritic species is poorly known. To date, continuous year-round monitoring has been undertaken at only 1 Antarctic station (Clarke et al. 1988). Data for single complete years are available for a few other stations (e.g. Fukuchi et al. 1985, Tokarczyk 1986, Domanov \& Lipski 1990, Kang \& Kang 1997, Kang et al. 1997). Between 1969 and 1983, seawater temperature, macronutrients, and chlorophyll were measured regularly at a coastal site close to the British Antarctic Survey research station on Signy Island, South Orkney Islands (Clarke et al. 1988). In this early study, distinction between different size-fractions was not made. Clarke \& Leakey (1996) measured seawater chl a concentration (size-fractionated at 20,2, and $0.2 \mu \mathrm{m}$ ) and temperature at Signy Island weekly from 1988 to 1994. 
There are 3 types of neritic microalgae in nearshore environments of Antarctica: phytoplankton, sea-ice microalgae, and benthic microalgae. The phytoplankton have been well examined in both offshore and inshore regions (Horne et al. 1969, Whitaker 1982, El-Sayed 1984, Fiala \& Oriol 1990). Sea-ice microalgae have also received much attention. Productivity measurements of the sea-ice algae indicate that they are an important source of organic carbon at their peak activity (Palmisano \& Sullivan 1983, McConville et al. 1985, Grossi et al. 1987, Palmisano et al. 1988, Kang et al. 1999). Benthic microalgae such as sediment-living

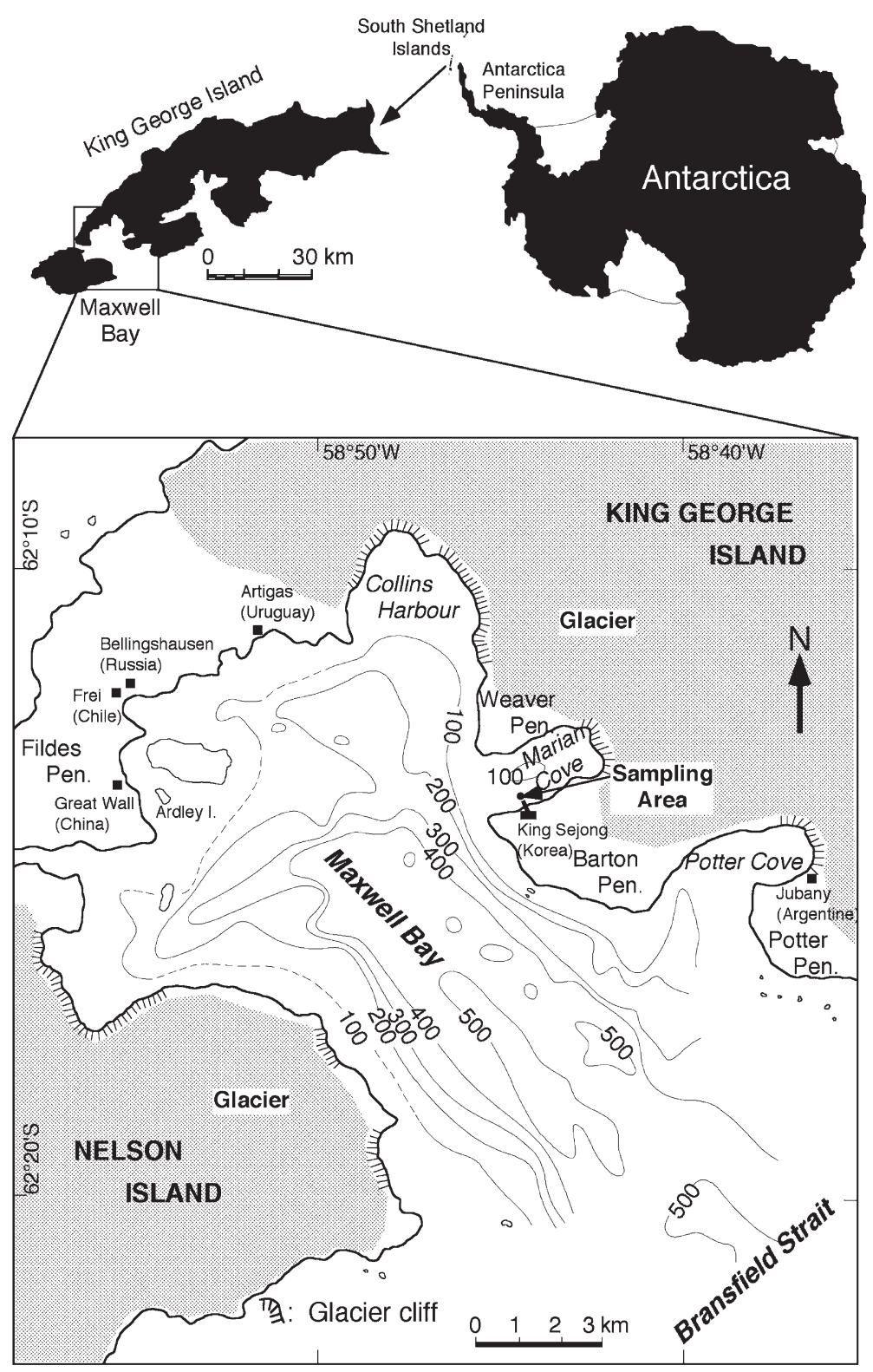

Fig. 1. Location of the sampling area (•) in Marian Cove, King George Island, Antarctica diatoms, epiphytic, and epilithic forms are also common in nearshore environments (Heywood \& Whitaker 1984). There have been a few studies on microphytobenthic algae, but investigations in the Antarctic and Arctic regions suggest that these microalgae may be important in primary production at certain times of the year (Horner \& Schrader 1982, Dayton et al. 1986,). Suspended benthic diatoms may contribute significantly to total primary production (Picken 1985, Klöser et al. 1994, Ahn et al. 1997), and benthic diatoms are assumed to be an important food source for benthic animals (Berkman et al. 1986, Ligowski 1983). Temporal variations in abundance of benthic diatoms are thus expected to have a significant influence on ecosystems of Antarctic nearshore environments. However, distributional patterns of benthic diatoms have been rarely studied.

Maxwell Bay shows open-water characteristics, as the bay mouth is open to Bransfield Strait and also has the characteristic of nearshore ecosystems. Therefore, microalgal populations comprise both benthic and pelagic species. In the present study, abundance, biomass, and species composition of micro- and nanoplanktonic microalgae were monitored at a fixed station in Marian Cove, King George Island (Fig. 1). The objectives of this study were (1) to observe the dominant species in the area, including nanoplanktonic microalgae; (2) to identify the major carbon source at coastal site; and (3) to determine microalgal succession during the annual cycle.

\section{MATERIALS AND METHODS}

Samples were collected at a fixed station in front of King Sejong Station from 11 January to 31 December 1996 ( $\mathrm{n}=273$ ) (Fig. 1). At this station the water is about $10 \mathrm{~m}$ deep and the water column is well mixed by wind and tidal currents. Water samples were taken at a depth of $0.5 \mathrm{~m}$ with a PVC bottle, and water temperature and salinity were measured with Sea-Bird 911 plus CTD (Otronix).

Water samples were transferred to the research station immediately after collection and were used to measure chl a concentration with Turner Design field fluorometer (Model 10-005R). The in vivo fluorescence values were calibrated with 
absolute chl a values. The chl a concentration was estimated spectrophotometrically (Parsons 1984). Particulates were collected on $25 \mathrm{~mm}$ glass fiber filters (GF/F) and the filters were then left in the dark for $12 \mathrm{~h}$ in $90 \%$ acetone at $4^{\circ} \mathrm{C}$ for pigment extraction. The linear relation ( $\mathrm{y}=0.8 \mathrm{x}-0.11, \mathrm{n}=55)$ between in vivo and absolute values was used to measure chl a concentrations $\left(\mathrm{mg} \mathrm{m}^{-3}\right)$. Size-fractionated study of chl a was conducted with $20 \mu \mathrm{m}$ nylon mesh. Cells which passed through the net were considered as pico- and nanoplankton chlorophyll $(<20 \mu \mathrm{m})$ and consisted mostly of flagellates, small diatoms, cyanobacteria, and cell fragments. Microplankton chlorophyll (>20 $\mu \mathrm{m})$ consisted essentially of colonial forms, chain-forming species and large single diatoms.

For nutrients (nitrate, phosphate and silicate), water samples $(500 \mathrm{ml})$ were filtered through a $47 \mathrm{~mm}$ GF/F and the filtrates were stored frozen in acidcleaned polyethylene bottles at $-45^{\circ} \mathrm{C}$. The samples were kept frozen with dry ice during transport to the Korea Ocean Research \& Development Institute (KORDI). Later in the lab, nutrient concentrations were determined with a Lachat Autoanalyzer. For suspended solids (SS), 11 of seawater was filtered on a pre-dried and weighed $\mathrm{GF} / \mathrm{F}$, and the filter was dried in a $60^{\circ} \mathrm{C}$ drying oven for $24 \mathrm{~h}$ and weighed. Total weight of suspended solids was calculated as the value of the filtered GF/F after drying minus the pre-dried and weighed $\mathrm{GF} / \mathrm{F}$.

Aliquots of $125 \mathrm{ml}$ were preserved with glutaraldehyde (final concentration 1\%) for microscopic analysis of micro- and nano-sized algae in the laboratory. Samples were filtered and mounted on slide glass with 2-hydroxypropyl methacrylate (HPMA). The HPMA slide-counting method was used for quantitative analysis on cell concentration and biomass (Kang 1993). At least 30 fields or 300 cells were enumerated using a Zeiss Axiophot microscope with a combination of light and epifluorescence microscopy at $400 \times$ for microplankton (cells $>20 \mu \mathrm{m}$ ), and at $1000 \times$ for autotrophic pico- and nanoplankton (Booth 1993). The micro- and nanoplanktonic microalgae were identified with a scanning electron microscope (SEM; Philips 515).

Conversions from cell count to cell carbon biomass were carried out as described previously by Kang et al. (1993). Cell dimensions of dominating microalgal species were measured to the nearest $1 \mu \mathrm{m}$ for subsequent estimations of biovolume using appropriate geometrical shape (Kang et al. 2001). The carbon biomass was estimated from the cell biovolume with the modified Strathmann equations (Smayda 1978).

The computer program Systat was used for the statistical treatment of the microalgal cell abundance and environmental data. Statistical analysis yielded Pear- son's correlation coefficient (r), which is the linear association between physicochemical variables and phytoplankton species that are normally distributed.

\section{RESULTS}

\section{Environments}

Maxwell Bay $\left(62^{\circ} 10-19^{\prime} \mathrm{S}, 58^{\circ} 35-58^{\prime} \mathrm{W}\right)$ is surrounded by King George Island and Nelson Island (Fig. 1). The mouth of Maxwell Bay is open to the southeast and water mass in the bay is influenced by the Bransfield Strait (Chang et al. 1990). The bay is about $18 \mathrm{~km}$ long and 6 to $14 \mathrm{~km}$ wide. Water depth gently increases from the coastline to $200 \mathrm{~m}$, but sharply increases from 200 to $400 \mathrm{~m}$. The central part of the bay is relatively flat, ranging from 400 to $500 \mathrm{~m}$ in depth.

Marian Cove is a tributary inlet of Maxwell Bay and one of the big fjords at King George Island. The bottom of Marian Cove and the adjacent open coasts consist of hard substrata (boulders, stones, pebbles, gravel, and sand) with macroalgal vegetation of changing density (Chung et al. 1991, 1994). During winter, surface water is covered with sea-ice or icebergs. In summer, surface ice melts and occasionally drifting floes are carried into the bay by wind. Freshwater input also occurs from land and submerged glaciers in summer. The details of hydrographic features of the bay during summer have been described by Chang et al. (1990).

\section{Seasonal characteristics of surface water at a fixed neritic station in Marian Cove}

Table 1 shows the physicochemical data recorded during 1996 (Kang et al. 1997). The study period was a 'warm year' showing an annual mean air temperature of $-0.7^{\circ} \mathrm{C}$, which is about $1.3^{\circ} \mathrm{C}$ higher than the mean of the last $8 \mathrm{yr}$ from 1988 to 1995 (avg. $-2.0^{\circ} \mathrm{C}$ ) measured at King Sejong Station (Kang et al. 1997). Annual mean temperature of surface water in Marian Cove was $-0.28^{\circ} \mathrm{C}$, about $0.4^{\circ} \mathrm{C}$ higher than air temperature (avg. $-0.7^{\circ} \mathrm{C}$ ). Annual mean salinity of seawater was 33.5 psu. Higher salinity (34.03 to 34.36 psu) was formed during austral winter (Table 1) and the lowest salinity was formed during February (avg. 31.97 psu), which is about $2.5 \mathrm{psu}$ lower than the highest in July (34.36 psu). The lowest salinity was due to high runoff of snow and glacial meltwater, because highest air temperature was observed in February. Also, the high meltwater in February might be the cause of low concentrations of nitrate, phosphate, and silicate and increase of suspended solids ( $\mathrm{SS}_{\text {; }}$ Table 1). Dilution 
Table 1. Monthly mean values of physicochemical variables (air temperature, water temperature, salinity, total chl a concentration, nanoplanktonic microalgal chl a concentration $[<20 \mu \mathrm{m}]$, microplanktonic microalgal chl a concentration [ $\geq 20 \mu \mathrm{m}]$, suspended solids [SS], nitrate, phosphate and silicate) recorded during 1996 (STD = standard deviation, $\mathrm{n}=$ sample size, temp. = temperature)

\begin{tabular}{|c|c|c|c|c|c|c|c|c|c|c|}
\hline & $\begin{array}{l}\text { Air } \\
\text { temp. } \\
\left({ }^{\circ} \mathrm{C}\right)\end{array}$ & $\begin{array}{l}\text { Water } \\
\text { temp. } \\
\left({ }^{\circ} \mathrm{C}\right)\end{array}$ & $\begin{array}{l}\text { Salinity } \\
\text { (psu) }\end{array}$ & $\begin{array}{c}\text { Total } \\
\text { chl a } \\
\left(\mathrm{mg} \mathrm{m}^{-3}\right)\end{array}$ & $\begin{array}{c}\text { Nano } \\
\mathrm{chl} \mathrm{a} \\
\left(\mathrm{mg} \mathrm{m}^{-3}\right)\end{array}$ & $\begin{array}{c}\text { Micro } \\
\text { chl a } \\
\left(\mathrm{mg} \mathrm{m}^{-3}\right)\end{array}$ & $\begin{array}{c}\text { SS } \\
\left(\mathrm{mg} \mathrm{l}^{-1}\right)\end{array}$ & $\begin{array}{l}\text { Nitrate } \\
(\mu \mathrm{M})\end{array}$ & $\begin{array}{c}\text { Phosphate } \\
(\mu \mathrm{M})\end{array}$ & $\begin{array}{l}\text { Silicate } \\
(\mu \mathrm{M})\end{array}$ \\
\hline $\begin{array}{l}\text { January } \\
\text { STD }(n=21)\end{array}$ & $\begin{array}{c}2.01 \\
(1.07)\end{array}$ & $\begin{array}{c}1.33 \\
(0.72)\end{array}$ & $\begin{array}{l}32.60 \\
(0.79)\end{array}$ & $\begin{array}{c}1.74 \\
(0.96)\end{array}$ & $\begin{array}{c}1.42 \\
(0.73)\end{array}$ & $\begin{array}{c}0.32 \\
(0.49)\end{array}$ & $\begin{array}{l}29.04 \\
(1.69)\end{array}$ & $\begin{array}{l}17.57 \\
(4.04)\end{array}$ & $\begin{array}{c}1.33 \\
(0.19)\end{array}$ & $\begin{array}{l}51.74 \\
(9.11)\end{array}$ \\
\hline $\begin{array}{l}\text { February } \\
\text { STD }(\mathrm{n}=29)\end{array}$ & $\begin{array}{c}2.72 \\
(1.37)\end{array}$ & $\begin{array}{c}1.23 \\
(0.39)\end{array}$ & $\begin{array}{l}31.97 \\
(0.60)\end{array}$ & $\begin{array}{c}1.60 \\
(0.86)\end{array}$ & $\begin{array}{c}1.28 \\
(0.76)\end{array}$ & $\begin{array}{c}0.32 \\
(0.21)\end{array}$ & $\begin{array}{l}29.53 \\
(2.47)\end{array}$ & $\begin{array}{l}16.30 \\
(3.99)\end{array}$ & $\begin{array}{l}1.23 \\
(0.17)\end{array}$ & $\begin{array}{c}45.27 \\
(14.60)\end{array}$ \\
\hline $\begin{array}{l}\text { March } \\
\text { STD }(n=29)\end{array}$ & $\begin{array}{c}1.53 \\
(2.44)\end{array}$ & $\begin{array}{c}0.88 \\
(0.45)\end{array}$ & $\begin{array}{l}32.26 \\
(0.48)\end{array}$ & $\begin{array}{c}1.28 \\
(1.29)\end{array}$ & $\begin{array}{c}0.82 \\
(0.39)\end{array}$ & $\begin{array}{c}0.46 \\
(0.94)\end{array}$ & $\begin{array}{l}29.13 \\
(3.33)\end{array}$ & $\begin{array}{l}18.50 \\
(2.93)\end{array}$ & $\begin{array}{c}1.37 \\
(0.17)\end{array}$ & $\begin{array}{l}58.21 \\
(9.08)\end{array}$ \\
\hline $\begin{array}{l}\text { April } \\
\text { STD }(\mathrm{n}=30)\end{array}$ & $\begin{array}{c}-1.02 \\
(2.91)\end{array}$ & $\begin{array}{c}0.08 \\
(0.41)\end{array}$ & $\begin{array}{l}33.39 \\
(0.55)\end{array}$ & $\begin{array}{c}0.79 \\
(0.34)\end{array}$ & $\begin{array}{c}0.61 \\
(0.23)\end{array}$ & $\begin{array}{c}0.19 \\
(0.15)\end{array}$ & $\begin{array}{l}27.04 \\
(1.37)\end{array}$ & $\begin{array}{l}16.84 \\
(3.51)\end{array}$ & $\begin{array}{c}1.28 \\
(0.16)\end{array}$ & $\begin{array}{c}51.85 \\
(10.22)\end{array}$ \\
\hline $\begin{array}{l}\text { May } \\
\text { STD }(\mathrm{n}=27)\end{array}$ & $\begin{array}{c}1.00 \\
(3.73)\end{array}$ & $\begin{array}{l}-0.55 \\
(0.55)\end{array}$ & $\begin{array}{l}33.50 \\
(0.53)\end{array}$ & $\begin{array}{c}0.65 \\
(0.38)\end{array}$ & $\begin{array}{c}0.51 \\
(0.29)\end{array}$ & $\begin{array}{c}0.13 \\
(0.11)\end{array}$ & $\begin{array}{l}28.75 \\
(3.28)\end{array}$ & $\begin{array}{l}16.29 \\
(3.25)\end{array}$ & $\begin{array}{c}1.33 \\
(0.21)\end{array}$ & $\begin{array}{c}49.77 \\
(11.02)\end{array}$ \\
\hline $\begin{array}{l}\text { June } \\
\text { STD }(n=19)\end{array}$ & $\begin{array}{c}-4.78 \\
(3.86)\end{array}$ & $\begin{array}{l}-1.33 \\
(0.38)\end{array}$ & $\begin{array}{l}34.29 \\
(0.49)\end{array}$ & $\begin{array}{c}0.25 \\
(0.11)\end{array}$ & $\begin{array}{c}0.21 \\
(0.08)\end{array}$ & $\begin{array}{c}0.04 \\
(0.04)\end{array}$ & $\begin{array}{l}27.10 \\
(1.35)\end{array}$ & $\begin{array}{l}17.07 \\
(3.31)\end{array}$ & $\begin{array}{c}1.34 \\
(0.17)\end{array}$ & $\begin{array}{l}51.09 \\
(9.94)\end{array}$ \\
\hline $\begin{array}{l}\text { July } \\
\text { STD }(\mathrm{n}=6)\end{array}$ & $\begin{array}{l}-3.40 \\
(3.77)\end{array}$ & $\begin{array}{l}-1.78 \\
(0.07)\end{array}$ & $\begin{array}{l}34.46 \\
(0.26)\end{array}$ & $\begin{array}{c}0.19 \\
(0.07)\end{array}$ & $\begin{array}{c}0.17 \\
(0.06)\end{array}$ & $\begin{array}{c}0.02 \\
(0.03)\end{array}$ & $\begin{array}{l}26.00 \\
(1.51)\end{array}$ & $\begin{array}{l}19.57 \\
(5.29)\end{array}$ & $\begin{array}{c}1.32 \\
(0.22)\end{array}$ & $\begin{array}{c}53.03 \\
(12.03)\end{array}$ \\
\hline $\begin{array}{l}\text { August } \\
\operatorname{STD}(\mathrm{n}=6)\end{array}$ & $\begin{array}{c}-3.59 \\
(3.62)\end{array}$ & $\begin{array}{l}-1.75 \\
(0.09)\end{array}$ & $\begin{array}{l}34.26 \\
(0.59)\end{array}$ & $\begin{array}{c}0.25 \\
(0.08)\end{array}$ & $\begin{array}{c}0.21 \\
(0.08)\end{array}$ & $\begin{array}{c}0.05 \\
(0.04)\end{array}$ & $\begin{array}{l}26.24 \\
(1.26)\end{array}$ & $\begin{array}{l}18.88 \\
(2.13)\end{array}$ & $\begin{array}{c}1.38 \\
(0.06)\end{array}$ & $\begin{array}{l}55.30 \\
(7.45)\end{array}$ \\
\hline $\begin{array}{l}\text { September } \\
\text { STD }(n=17)\end{array}$ & $\begin{array}{c}-1.38 \\
(2.89)\end{array}$ & $\begin{array}{l}-1.33 \\
(0.48)\end{array}$ & $\begin{array}{l}34.02 \\
(0.89)\end{array}$ & $\begin{array}{c}0.77 \\
(0.48)\end{array}$ & $\begin{array}{c}0.60 \\
(0.29)\end{array}$ & $\begin{array}{c}0.17 \\
(0.21)\end{array}$ & $\begin{array}{l}27.45 \\
(2.00)\end{array}$ & $\begin{array}{l}19.63 \\
(2.58)\end{array}$ & $\begin{array}{c}1.42 \\
(0.14)\end{array}$ & $\begin{array}{l}63.35 \\
(8.22)\end{array}$ \\
\hline $\begin{array}{l}\text { October } \\
\text { STD }(n=29)\end{array}$ & $\begin{array}{c}-1.28 \\
(2.12)\end{array}$ & $\begin{array}{l}-0.95 \\
(0.44)\end{array}$ & $\begin{array}{l}33.95 \\
(0.40)\end{array}$ & $\begin{array}{c}1.33 \\
(1.53)\end{array}$ & $\begin{array}{c}0.80 \\
(0.78)\end{array}$ & $\begin{array}{c}0.52 \\
(0.81)\end{array}$ & $\begin{array}{l}27.79 \\
(2.24)\end{array}$ & $\begin{array}{l}16.12 \\
(3.80)\end{array}$ & $\begin{array}{c}1.05 \\
(0.32)\end{array}$ & $\begin{array}{c}43.35 \\
(17.40)\end{array}$ \\
\hline $\begin{array}{l}\text { November } \\
\text { STD }(n=30)\end{array}$ & $\begin{array}{c}-0.08 \\
(1.69)\end{array}$ & $\begin{array}{l}-0.08 \\
(0.41)\end{array}$ & $\begin{array}{l}33.79 \\
(0.57)\end{array}$ & $\begin{array}{c}3.82 \\
(6.87)\end{array}$ & $\begin{array}{c}0.99 \\
(1.02)\end{array}$ & $\begin{array}{c}2.83 \\
(5.88)\end{array}$ & $\begin{array}{l}29.47 \\
(4.10)\end{array}$ & $\begin{array}{l}13.70 \\
(3.20)\end{array}$ & $\begin{array}{c}0.98 \\
(0.21)\end{array}$ & $\begin{array}{l}31.76 \\
(9.80)\end{array}$ \\
\hline $\begin{array}{l}\text { December } \\
\text { STD }(n=30)\end{array}$ & $\begin{array}{c}1.14 \\
(1.30)\end{array}$ & $\begin{array}{c}0.81 \\
(0.70)\end{array}$ & $\begin{array}{l}33.60 \\
(0.53)\end{array}$ & $\begin{array}{c}3.28 \\
(4.94)\end{array}$ & $\begin{array}{l}1.20 \\
(0.97)\end{array}$ & $\begin{array}{c}2.09 \\
(4.06)\end{array}$ & $\begin{array}{l}31.80 \\
(6.57)\end{array}$ & $\begin{array}{l}12.09 \\
(3.01)\end{array}$ & $\begin{array}{c}1.08 \\
(0.22)\end{array}$ & $\begin{array}{c}42.82 \\
(12.36)\end{array}$ \\
\hline
\end{tabular}

might have played a primary role in reducing surface nutrient concentrations during February (Brandini \& Rebello 1994).

The annual mean values of nitrate, phosphate, and silicate are $17,1.3$, and $49.9 \mu \mathrm{M}$, respectively. Annual mean value of SS including organic and inorganic matters (Ahn et al. 1997) was $29.05 \mathrm{mg} \mathrm{l}^{-1}$. The concentrations of nitrate, phosphate, and silicate generally increased throughout the year until September and decreased abruptly with an increase of microalgal biomass in early October (Table 1). The concentration of $\mathrm{SS}$ is also high from October to December. An increase of microalgal biomass from October onwards is indicative of a primary role of microalgal bloom on the low concentrations of nutrients and high SS concentration. The influence of glacial meltwater might have been minimal, since air temperature was still low and no significant increase in meltwater run-off was observed. The relatively high salinity during this period is also suggestive of a minimal role of glacial meltwater.
Annual mean of total chl a concentration in surface water was $1.38 \mathrm{mg} \mathrm{m}^{-3}$. A feature of microalgal biomass in Marian Cove was characterized by multimodal distribution of standing crop during the study period. chl a concentration showed a marked seasonality (Table 1). Monthly mean of total chl a concentrations in January and February were 1.74 and $1.61 \mathrm{mg} \mathrm{m}^{-3}$, respectively. After March $\left(1.27 \mathrm{mg} \mathrm{m}^{-3}\right)$, the chl a concentration declined rapidly, showing low values $<1 \mathrm{mg}$ $\mathrm{m}^{-3}$ during the period of April to September. A bloom started in October (1.33 $\mathrm{mg} \mathrm{m}^{-3}$ ), resulting in high chl a concentrations during November and December (3.82 and $3.90 \mathrm{mg} \mathrm{m}^{-3}$, respectively). The pattern of monthly mean of nanoplanktonic microalgal $(<20 \mu \mathrm{m}$, including pico-planktonic microalgae) chl a concentrations showed a similar pattern to that of total chl a concentration. Mean value of nanoplanktonic microalgal chl a concentration during austral spring (September, October and November) and summer (December, January and February) accounted for 0.81 and $1.34 \mathrm{mg} \mathrm{m}^{-3}$, 
respectively. During autumn (March, April and May) and winter (June, July and August) the values were $0.65 \mathrm{mg} \mathrm{m}^{-3}$ and $0.19 \mathrm{mg} \mathrm{m}^{-3}$, respectively. Microplanktonic microalgal $(>20 \mu \mathrm{m}) \mathrm{chl} a$, however, showed low concentration from January to October (Table 1). The microplanktonic microalgal chl a increased abruptly during November (2.83 $\mathrm{mg} \mathrm{m}^{-3}$ ) with a peak concentration of $31.17 \mathrm{mg} \mathrm{m}^{-3}$ on 28 November.
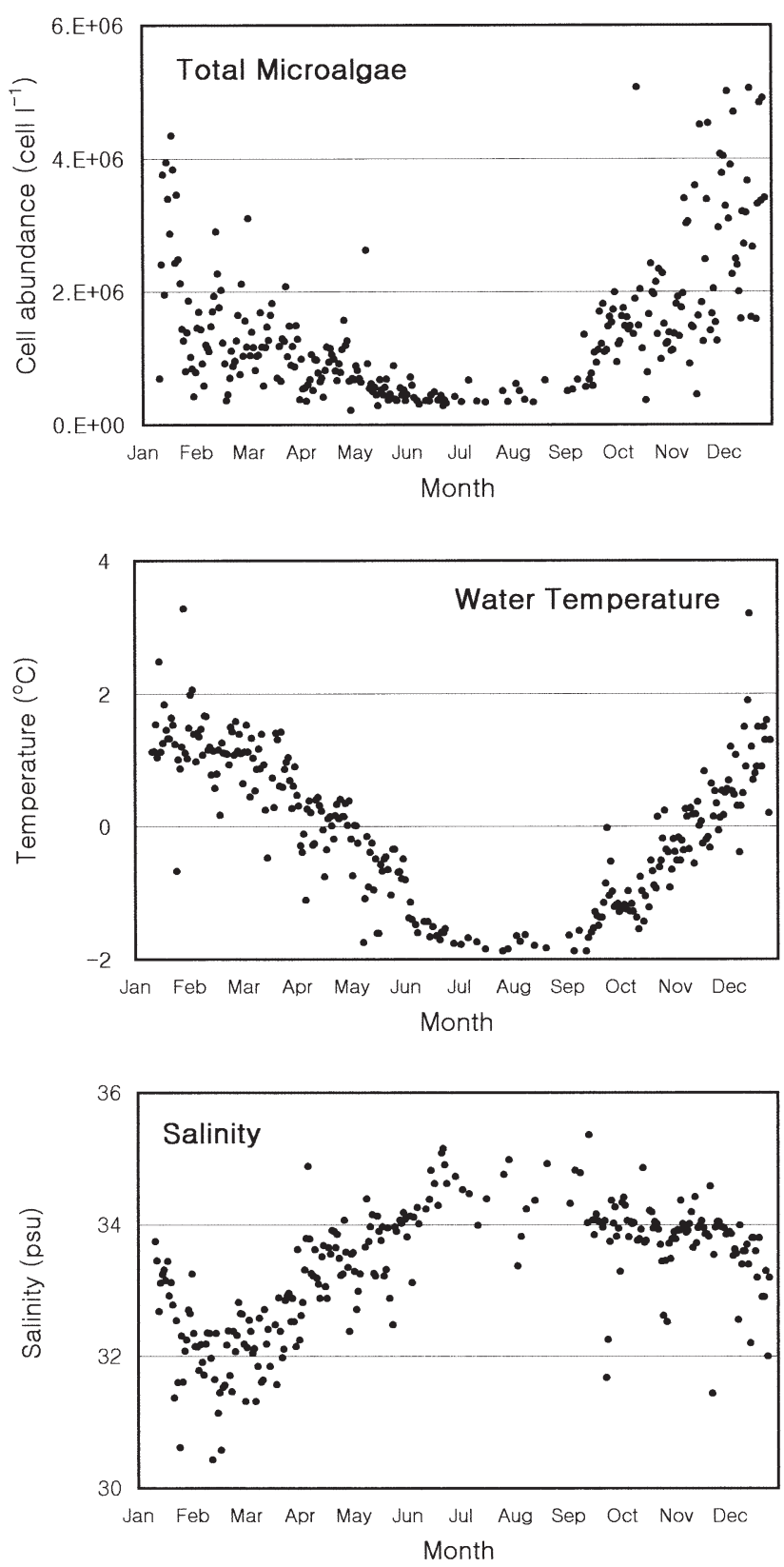

Fig. 2. Seasonal variation of total microalgal cell abundance (MCA), water temperature, and salinity

\section{Seasonal variation of microalgal abundance}

Annual mean of total microalgal cell abundance

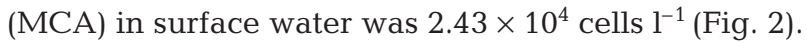
Monthly mean of total MCA in January and February were $2.21 \times 10^{6}$ and $1.31 \times 10^{6}$ cells $1^{-1}$, respectively. After March $\left(1.28 \times 10^{6}\right.$ cells $\left.\mathrm{l}^{-1}\right)$ the abundance declined, reaching levels below $1 \times 10^{6}$ cells $\mathrm{l}^{-1}$ during April and August. A bloom started in September $\left(1.02 \times 10^{6}\right.$ cells $\left.1^{-1}\right)$ and the abundance of microalgae increased abruptly during October and November $\left(1.68 \times 10^{6}\right.$ and $2 \times 10^{6}$ cells $^{-1}$, respectively) peaking in December $\left(3.17 \times 10^{6}\right.$ cells $\left.1^{-1}\right)$. The highest MCA was $5.07 \times 10^{6}$ cells $1^{-1}$ on 17 October.

The nanoplanktonic microalgae (including nanosized flagellates and diatoms) such as Cryptomonas spp., Phaeocystis antarctica and Navicula glaciei were observed in high numbers in January $\left(2.20 \times 10^{6}\right.$ cells

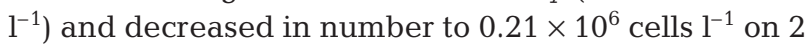
May (Fig. 3). Monthly mean of nanoplanktonic MCA in January and February were $2.20 \times 10^{6}$ and $1.27 \times$ $10^{6}$ cells $^{-1}$, respectively (Fig. 4). After March $(1.24 \times$ $10^{6}$ cells $\mathrm{l}^{-1}$ ), the abundance declined, reaching levels below $1 \times 10^{6}$ cells $1^{-1}$ during April and August. Nanoplanktonic microalgae started to bloom in October $\left(1.57 \times 10^{6}\right.$ cells $\left.^{-1}\right)$ and abruptly increased in number

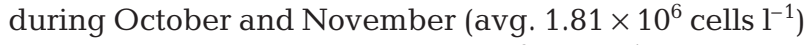

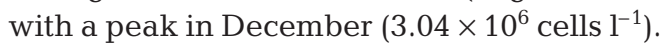

The abundance of microplanktonic microalgae (including most diatoms), however, was low from January to September and then increased to $1.47 \times$ $10^{6}$ cells $1^{-1}$ on 28 November (Fig. 3). Fragilaria striatula was the most abundant species among microplanktonic microalgae on that day. Monthly mean abundance of microplanktonic microalgae from January to September was $0.02 \times 10^{6}$ cells $\mathrm{l}^{-1}$. Monthly mean of microplanktonic MCA increased dramatically during October and November $\left(0.11 \times 10^{6}\right.$ and $0.19 \times 10^{6}$ cells $\mathrm{l}^{-1}$, respectively) and decreased in December $(0.13 \times$

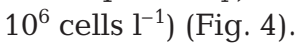

The most abundant phytoflagellate, Phaeocystis antarctica, occurred only in the motile flagellate form. Abundance of $P$. antarctica and other unidentified nanoplanktonic microalgae $(5 \pm 2 \mu \mathrm{m})$ was relatively high during the study period (Fig. 5). Monthly mean of abundance in January was $2.09 \times 10^{6}$ cells $1^{-1}$ (Fig. 5). After February $\left(1.15 \times 10^{6}\right.$ cells $\left.1^{-1}\right)$, abundance declined, reaching levels below $1 \times 10^{6}$ cells $\mathrm{l}^{-1}$ from April to September. A bloom started in September $\left(0.85 \times 10^{6}\right.$ cells $\left.^{-1}\right)$ and abundance increased abruptly during October and November $\left(1.13 \times 10^{6}\right.$ and $1.36 \times$ $10^{6}$ cells $1^{-1}$, respectively) and peaked in December

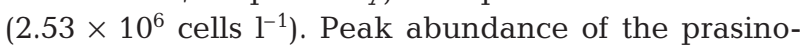

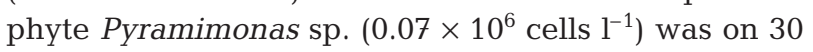
December, coinciding with the bloom of $P$. antarctica 

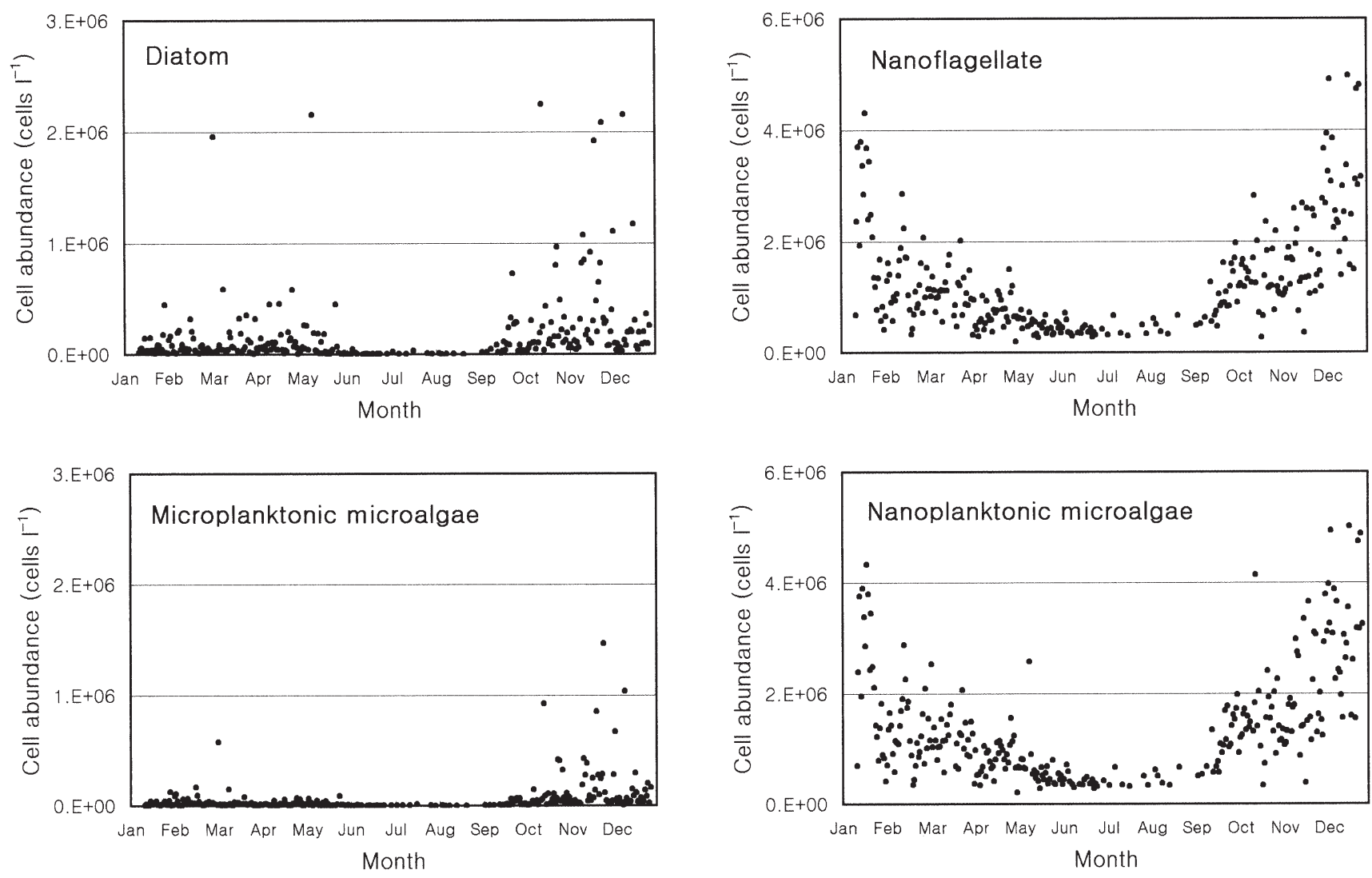

Fig. 3. Seasonal variation in cell abundance of diatoms, nanoflagellate, microplanktonic microalgae and nanoplanktonic microalgae

(Fig. 5). Cryptomonas spp., the second-most abundant phytoflagellate, was observed in high numbers during

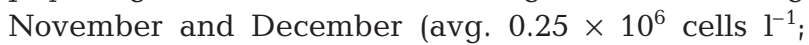
Fig. 5), accounting for $65.4 \%$ of total abundance of Cryptomonas spp.

Total diatom abundance showed a bimodal distribution (Fig. 4) with high values in March to May and November. In contrast, abundance of microplanktonic microalgae (most diatoms except Minidiscus spp., Navicula glaciei/perminuta, and Rhoikosphenia sp.) did not show a peak during March and May (Fig. 4), which is the time of highest $N$. glaciei/perminuta abundance (Fig. 5). The concentration of most diatoms increased rapidly during September and October. Especially benthic diatoms, such as Achnanthes groenlandica, Fragilaria striatula, Licmophora belgicae, and L. gracilis bloomed during October and November.

The most abundant microplanktonic diatom was Fragilaria striatula. This species showed large bimodal distribution (Fig. 6). The number of F. striatula was low from January to early October. Abundance of $F$. striatula increased dramatically to $8.42 \times 10^{5}$ cells $\mathrm{l}^{-1}$ on 28 November and then decreased during December (avg.
$6.70 \times 10^{4}$ cells $^{-1}$ ). Abundance between October and December (avg. $8.37 \times 10^{4}$ cells $\mathrm{l}^{-1}$ ) accounted for $79.3 \%$ of annual mean abundance of $F$. striatula (Fig. 6). In the case of Licmophora belgicae, abundance was low from January to October and increased abruptly in November. Abundance during November

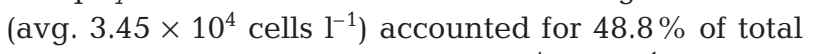
abundance of $L$. belgicae $\left(7.06 \times 10^{4}\right.$ cells $\left.\mathrm{l}^{-1}\right)$.

On the other hand, temporal variations of planktonic diatoms, such as Thalassiosira spp. (mainly T. antarctica, T. tumida, T. dichotomica and T. gracilis), Actinocyclus actinochilus, and Nitzschia lecointei were dissimilar to those of benthic diatoms. Both size classes of Thalassiosira spp. $(<20 \mu \mathrm{m}$ and $>20 \mu \mathrm{m})$ did not show a decrease in austral summer (Fig. 6). Highest mean abundance of both groups of $T$. spp. appeared in July $\left(9.61 \times 10^{4}\right.$ and $7.94 \times 10^{4}$ cells $1^{-1}$, respectively). The large planktonic diatom Corethron pennatum $(=C$. criophilum) was observed in low numbers from January to early October (Fig. 6). Abundance increased dramatically to $4.51 \times 10^{4}$ cells $1^{-1}$ on 20 November and then decreased rapidly during December (avg. $1.80 \times$ $10^{2}$ cells $\mathrm{l}^{-1}$ ). Abundance during November (avg. $6.20 \times$ 

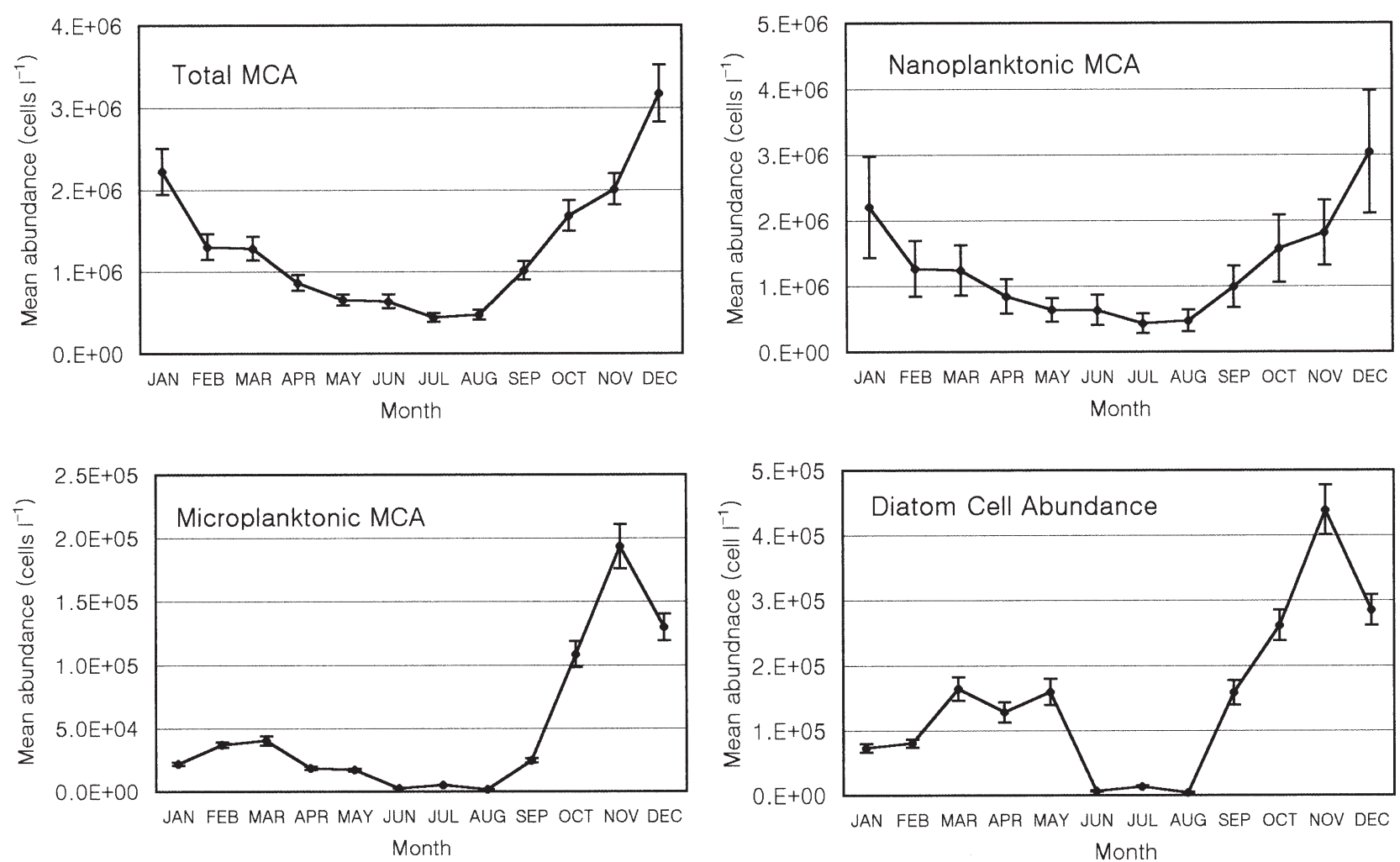

Fig. 4. Seasonal changes in monthly mean values of total microalgal cell abundance (MCA), microplanktonic MCA, nanoplanktonic MCA, and diatom cell abundance
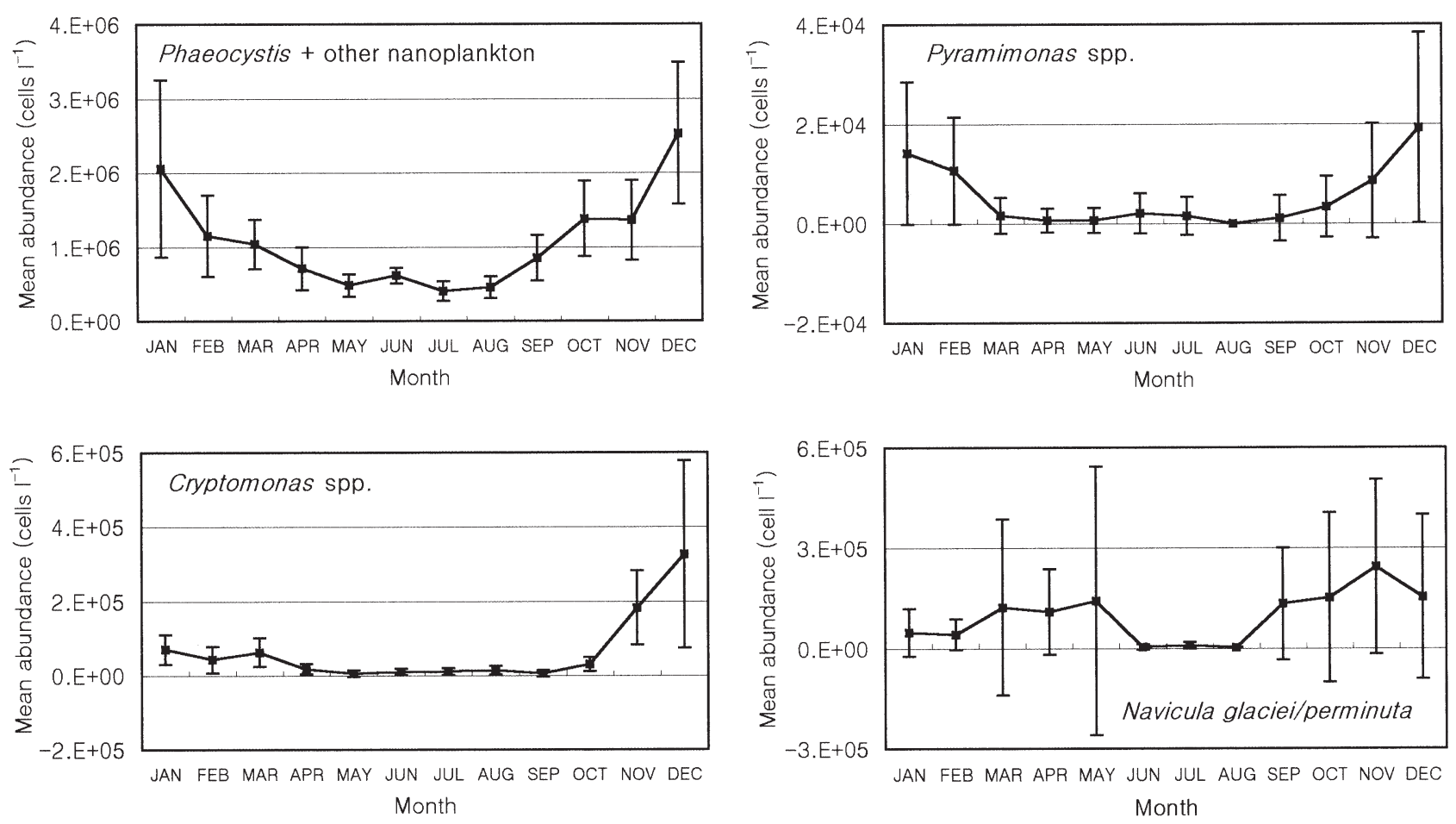

Fig. 5. Seasonal changes in monthly mean values of nanoplanktonic microalgal cell abundance (Phaeocysitis antarctica and other unidentified nanoplankton, Pyramimonas spp., Cryptomonas spp., and Navicula glaciei and N. perminuta) 

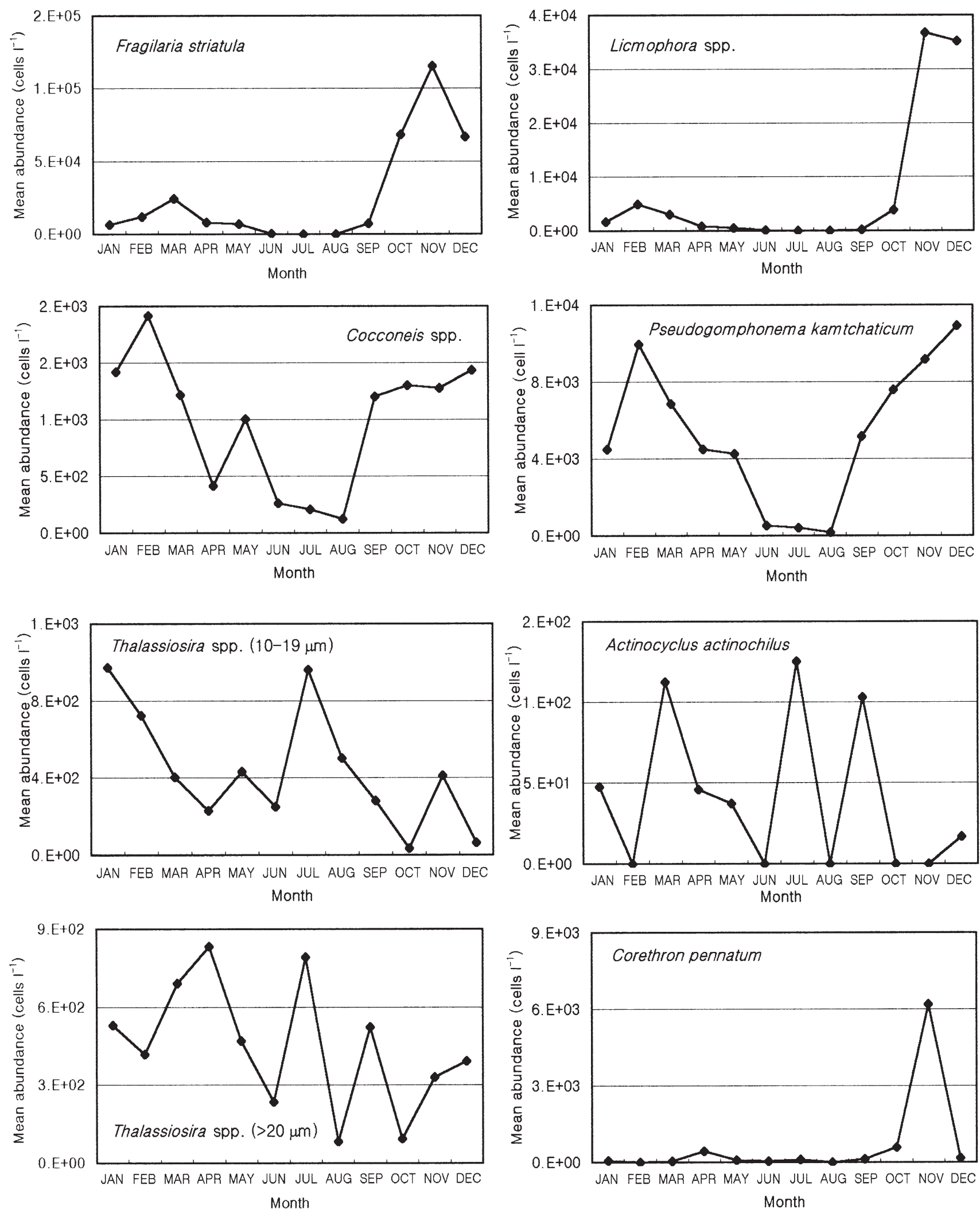

Fig. 6. Seasonal changes in monthly mean values of microplanktonic microalgal cell abundance (Fragilaria striatula, Licmophora spp., Cocconeis spp., Pseudogomphonema lcamtchaticm Thalassiosira spp. (10 to $19 \mu \mathrm{m})$, Actinocyclus actinochilus, Thalassiosira spp. $(>20 \mu \mathrm{m})$ and Corethron pennatum) 
$10^{3}$ cells $1^{-1}$ ) accounted for $78.7 \%$ of total abundance of C. pennatum $\left(7.88 \times 10^{3}\right.$ cells $\left.\mathrm{l}^{-1}\right)$.

Cryophilic diatoms Navicula glaciei and N. perminuta were the most abundant species of nanoplanktonic diatoms, showing higher numbers than other diatoms during all seasons. Because both species were not easy to identify with the use of light microscopy (LM), we did not split up the 2 species. Monthly mean abundance of Navicula glaciei/perminuta is shown in Fig. 5. Annual mean abundance of $N$. glaciei/perminuta in surface water was $9.69 \times 10^{4}$ cells $\mathrm{l}^{-1}$. Abundance was low from December to February and June to August, whereas it was high from March to May and September to November (Fig. 5). Monthly mean abundance was highest in November $\left(2.44 \times 10^{5}\right.$ cells $\left.1^{-1}\right)$ and then decreased during December $(1.54 \times$ $10^{3}$ cells $1^{-1}$ ).

\section{Microalgal abundance in relation to environmental factors}

In order to see the relation between the physicochemical factors and microalgal abundance, we used Pearson's correlation matrix based on daily values (Table 2).

Total MCA was positively correlated with air temperature $(r-v a l u e=0.29, n=273, p<0.01$, Table 2a). No significant correlations were observed between microplanktonic MCA and either air temperature or water temperature. However, significant correlations were seen between nanoplanktonic MCA and both temperatures (r-values $=0.30$ and 0.41 , respectively, $\mathrm{n}=273$ ). Also, MCA of nanoflagellate showed a positive correlation with air and water temperatures (r-values $=0.31$ and 0.43 , respectively, $\mathrm{n}=273$ ), whereas

Table 2. Pearson's correlation matrix of biological or environmental parameters $(n=273)$. The $r$-values shown in this table indicate statistical significance when $p$-values are $<0.01$. Asterisks indicate that $r$-values are not significant. (a) Correlation coefficients between salinity (SAL), air temperature (AIR), water temperature (WAT), wind speed (WIN), suspended solids (SS), nitrate (NIT), phosphate (PHO), silicate (SIL), total microalgae (TOT), nanoplanktonic microalgae (NAN), microplanktonic microalgae (MIC), nanoflagellate microalgae (NA-F) and diatom (DIA). (b) Correlation coefficients between salinity (SAL), air temperature (AIR), water temperature (WAT), wind speed (WIN), suspended solids (SS), nitrate (NIT), phosphate (PHO), silicate (SIL), Cryptomonas sp. (CRY), Phaeocystis antarctica (PHA), Cocconeis spp. (COC), Corethron pennatum (COR), Fragilaria striatula (FRA), Licmophora spp. (LIC), Navicula spp. (NAV), Pseudogomphonema kamtchaticum (PSE) and Thalassiosira spp. (THA)

\begin{tabular}{|c|c|c|c|c|c|c|c|c|c|c|c|c|c|}
\hline (a) & SAL & AIR & WAT & WIN & SS & NIT & PHO & SIL & TOT & NAN & MIC & NA-F & DIA \\
\hline Salinity & 1 & & & & & & & & & & & & \\
\hline Air temperature & -0.58 & 1 & & & & & & & & & & & \\
\hline Water temperature & -0.60 & 0.60 & 1 & & & & & & & & & & \\
\hline Wind speed & * & * & -0.22 & 1 & & & & & & & & & \\
\hline Suspended solids & * & 0.25 & 0.17 & * & 1 & & & & & & & & \\
\hline Nitrate & * & * & -0.20 & * & * & 1 & & & & & & & \\
\hline Phosphate & * & * & -0.07 & * & * & 0.80 & 1 & & & & & & \\
\hline Silicate & * & * & * & * & * & 0.81 & 0.94 & 1 & & & & & \\
\hline Total microalgae & * & 0.29 & * & * & 0.31 & -0.31 & -0.28 & -0.20 & 1 & & & & \\
\hline Nano-microalgae & * & 0.30 & 0.41 & * & 0.27 & -0.29 & -0.26 & -0.18 & 0.99 & 1 & & & \\
\hline Micro-microalgae & * & ${ }^{*}$ & * & * & 0.42 & -0.26 & -0.24 & -0.22 & 0.53 & 0.42 & 1 & & \\
\hline Nanoflagellate microalgae & * & 0.31 & 0.43 & * & 0.22 & -0.26 & -0.22 & * & 0.95 & 0.97 & 0.29 & 1 & \\
\hline Diatom & * & * & ${ }^{*}$ & * & 0.37 & -0.26 & -0.24 & -0.20 & 0.50 & 0.41 & 0.87 & 0.20 & 1 \\
\hline
\end{tabular}

\begin{tabular}{|c|c|c|c|c|c|c|c|c|c|c|c|c|c|c|c|c|c|}
\hline (b) & SAL & AIR & WAT & WIN & SS & NIT & $\mathrm{PHO}$ & SIL & CRY & PHA & $\mathrm{COC}$ & COR & FRA & LIC & NAV & PSE & THA \\
\hline Salinity & 1 & & & & & & & & & & & & & & & & \\
\hline Air temperature & -0.58 & 1 & & & & & & & & & & & & & & & \\
\hline Water temperature & -0.60 & 0.60 & 1 & & & & & & & & & & & & & & \\
\hline Wind speed & ${ }^{*}$ & ${ }^{*}$ & -0.22 & 1 & & & & & & & & & & & & & \\
\hline Suspended solids & $*$ & 0.25 & 0.17 & * & 1 & & & & & & & & & & & & \\
\hline Nitrate & $*$ & * & -0.20 & $*$ & $*$ & 1 & & & & & & & & & & & \\
\hline Silicate & * & * & $*$ & * & * & 0.81 & 0.94 & 1 & & & & & & & & & \\
\hline Cryptomonas sp. & * & 0.20 & 0.30 & $*$ & 0.24 & -0.33 & -0.27 & -0.22 & 1 & & & & & & & & \\
\hline Phaeocystis + other nanoplanktonic microalge & * & 0.31 & 0.42 & * & 0.20 & -0.23 & -0.21 & -0.14 & 0.59 & 1 & & & & & & & \\
\hline Cocconeis spp. & -0.21 & 0.32 & 0.17 & 0.27 & 0.31 & $*$ & ${ }^{*}$ & * & ${ }^{*}$ & 0.20 & 1 & & & & & & \\
\hline Corethron pennatum & * & * & * & * & * & -0.27 & -0.32 & -0.34 & 0.27 & * & 0.17 & 1 & & & & & \\
\hline Fragilaria striatula & * & * & * & * & 0.35 & -0.25 & -0.25 & -0.22 & 0.23 & 0.51 & 0.30 & 0.26 & 1 & & & & \\
\hline Licmophora spp. & $*$ & * & $*$ & $*$ & 0.52 & -0.23 & * & * & 0.26 & 0.25 & 0.22 & 0.16 & 0.80 & 1 & & & \\
\hline Navicual glaciei/perminuta & 0.23 & ${ }^{*}$ & * & $*$ & 0.27 & -0.22 & -0.20 & $*$ & * & * & 0.31 & 0.29 & 0.64 & 0.43 & 1 & & \\
\hline Thalassiosira spp. & $*$ & * & 0.17 & $*$ & $*$ & * & 0.17 & * & * & 0.17 & -0.07 & * & $*$ & $*$ & * & $*$ & 1 \\
\hline
\end{tabular}


diatom was not significantly correlated with either temperature. This suggests that the bloom of nanoplanktonic flagellate was induced by temperature increase. Nanoflagellates, Cryptomonas spp. and Phaeocystis antarctica were the only species showing significant positive correlation with both temperatures (Table $2 \mathrm{~b}$ ).

Salinity was negatively correlated with air and water temperatures (r-values $=-0.58$ and $-0.60, \mathrm{n}=273$, Table 2a). Little correlation was observed between MCA and salinity, but Cocconeis spp. and Pseudogomphonema kamtschaticum were negatively correlated with salinity (Table 2b). These species, which were positively correlated with air temperature and wind speed, were found only on subtidal macroalgae such as the red alga Plocamium cartilagineum ( $<5$ to $30 \mathrm{~m}$ ) and the brown algae Desmarestia spp., the most dominant macroalgae in the depth range of 5 to $15 \mathrm{~m}$ during austral summer (Ahn et al. 1997).

Significant correlations were seen between MCA and concentration of SS (Table 2a). Abundant microalgal species, except the planktonic diatoms, Corethron pennatum and Thalassiosira spp., were positively correlated with SS. Ahn et al. (1997) also reported a significant correlation between chl a concentration and SS in Maxwell Bay during austral summer. These correlations indicate that increase of SS was influenced by benthic diatoms during summer (see 'Discussion').

Nutrients such as nitrate, phosphate, and silicate were negatively correlated with MCA, which probably reflects microalgal uptake (Table 2). Not only microplanktonic MCA and diatoms but also nanoplanktonic MCA were significantly correlated with nutrients. Abundance of nanoflagellates, which have no silicate theca, was not negatively correlated with silicate. This means that the dramatic increase of microalgae significantly affected the decrease of nutrients. Benthic diatoms such as Cocconeis spp. and Pseudogomphonema kamtschaticum, however, were not significantly correlated with nutrients.

\section{DISCUSSION}

\section{Seasonal variation of microalgal abundance in relation to environmental factors}

Total chl a concentration showed low values $<1 \mathrm{mg}$ $\mathrm{m}^{-3}$ during the period of April to September (Fig. 5). In Factory Cove, the lowest chl a concentration was observed in July $\left(0.23 \mathrm{mg} \mathrm{m}^{-3}\right.$ ) (Clarke et al. 1988). In Marian Cove, MCA was low during winter, with a minimum monthly mean of $4.4 \times 10^{5}$ cells $\mathrm{l}^{-1}$ in July. The abundance of Phaeocystis antarctica and other unidentified nanoplanktonic microalgae $(5 \pm 2 \mu \mathrm{m})$ was relatively high during winter.
Total chl a increased during summer. The nanoplanktonic diatoms, Navicula glaciei/perminuta, started to increase in abundance at the beginning of spring, when other microplanktonic microalgae (especially diatoms) also began to bloom (Fig. 4). Microalgal bloom started in October and abruptly increased in abundance during November 1996 (Table 1). More than $45 \%$ (avg. $3.5 \mathrm{mg} \mathrm{m}^{-3}$ ) of chl a was concentrated during November and December. In Factory Cove, chl a started to increase in November, climbed very rapidly during December, and peaked in January (Clarke et al. 1988). The microalgal bloom started on average about 2 mo earlier in Marian Cove than in Factory Cove.

Nanoplanktonic microalgae also increased during summer (Fig. 4). In October, nanoflagellate Cryptomonas spp. started to increase in abundance and then continuously increased until December (Fig. 5). According to Moline et al. (2000), cryptophytes were dominant in low salinity water characteristic of the meltwater input near Anvers Island. Also, a cryptophyte bloom was observed in the upper $20 \mathrm{~m}$ of the water column within the coastal polynya between 76.0 and $76.5^{\circ} \mathrm{S}$ (Arrigo et al. 1999). In the Weddell-ScotiaBellingshausen Confluence areas crytophytes have been found to make a major contribution to the total biomass along the retreating ice-edge zones (Buma et al. 1992).

In our data, Cryptomonas spp. was significantly correlated with air and water temperatures during 1996, showing positive correlations with both temperatures from October to December (r values $=0.38$ and 0.56, respectively; $\mathrm{n}=89, \mathrm{p}<0.01$ ). It was not significantly correlated with salinity, wind speed and SS. Salinity showed neither normal correlation nor lag correlation with Cryptomonas spp. Such a positive correlation between Cryptomonas spp. and temperature has been observed in the Bransfield Strait (Kang \& Lee 1995, Mura \& Agustí 1998, Kang et al. 2001). There, the growth of cryptophytes was highly responsive to small changes in water temperature and relatively warm water (ca. $2.4^{\circ} \mathrm{C}$ ) was the optimal temperature for the growth of the cryptomonad (Mura \& Agustí 1998). In Anvers Island, cryptophytes also showed a positive correlation with the daily mean air temperature during the 5-yr study period (Moline et al. 2000). The increase in air temperature decreased salinity because of ice melting, and subsequently increased water temperature. The latter stimulated the growth of cryptophytes (Mura \& Agustí 1998). In our study, the insignificant correlation between salinity and Cryptomonas spp. is also suggestive of the minimal role of salinity in the growth of cryptophytes. Sea ice had already retreated far from the study site during the period of Cryptomonas spp. bloom (November to December). 

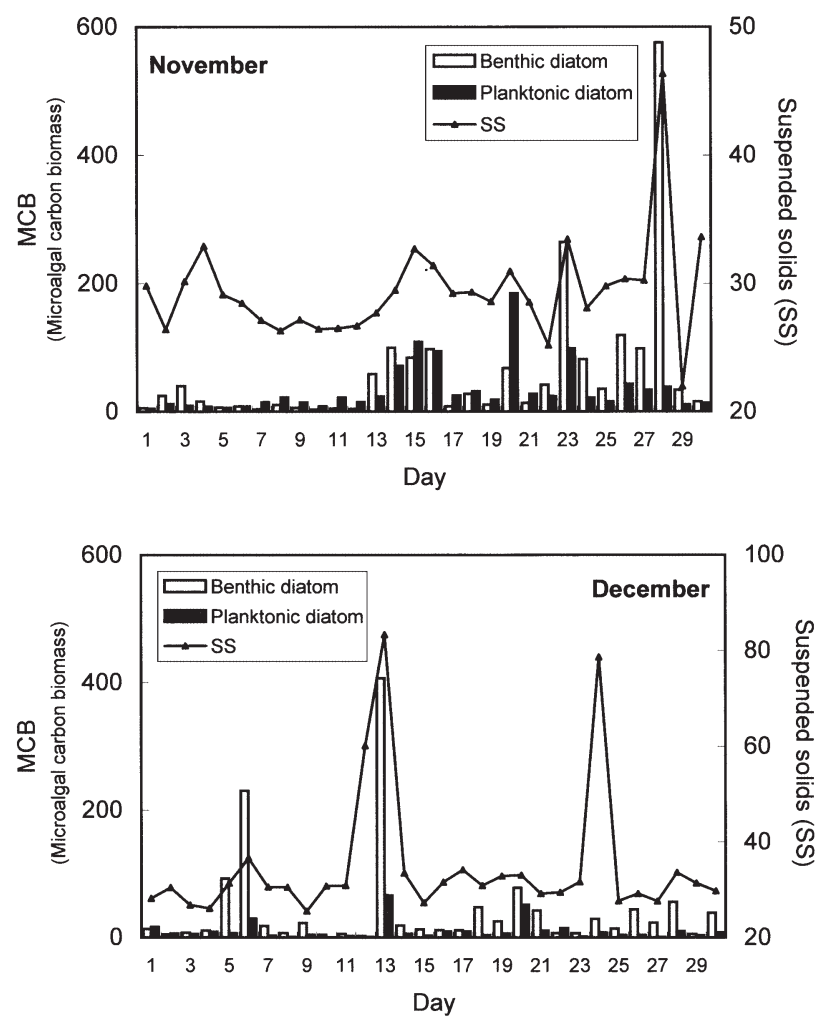

Fig. 7. Comparison of suspended solids (SS) and microalgal carbon biomass (MCB) of benthic and planktonic diatoms in November and December

Microplanktonic microalgae were also increased during summer (Fig. 4). High diatom biomass during November and December was caused by tychoplanktonic benthic diatoms from the sea bottom, not by in situ production and growth of phytoplankton. Fig. 7 shows the microalgal carbon biomass of benthic and planktonic diatoms in November and December. As planktonic biomass was low in the water column for a large part of the summer growing season, such an increase in benthic diatoms would have an important role on the increase of chlorophyll. The proportion of total benthic diatoms to the total microalgal species was also consistently high in November and December (83 and 61\%, respectively) near Davis Station (Everitt \& Thomas 1986).

Total diatom and benthic diatom carbon biomass were positively correlated with SS (r-values 0.43 and 0.47 , respectively; $\mathrm{n}=60, \mathrm{p}<0.01$ ) in November and December. SS comprise inorganic and organic matters that were usually supplied by meltwater streams, resuspen- sion of benthic material, and subglacial discharge during summer. The inorganic matter (mostly sediment) accounted for $>80 \%$ of total SS in Marian Cove (Ahn et al. 1997). It was most likely supplied by wind-driven resuspension of sea-bottom material and by terrigenous input from meltwater run-off. Although SS was not significantly correlated with wind speed, resuspension of benthic diatoms from the sea bottom due to wind-induced turbulence might be affecting the secondary production of adjacent waters (Demers et al. 1987, Brandini \& Rebello 1994). Brandini \& Rebello (1994) reported that the strong turbulence generated by winds resuspended benthic diatoms from the sediment of the inner shallow sections of the Admiralty Bay. In other areas of Antarctic coastal environments, resuspension of sublittoral deposit has been suggested as a primary process for increasing suspended solids (Krebs 1983, Berkman et al. 1986, Everitt \& Thomas 1986, Dunbar et al. 1989, Gilbert 1991, Brandini \& Rebello 1994, Klöser et al. 1994, Ahn et al. 1997). The resuspension of benthic microalgae would significantly affect secondary production and the diversity of nearshore phytoplankton assemblages (Ahn 1996).

Abundant benthic diatoms such as Fragilaria striatula, Licmophora belgicae, and L. gracilis were densely attached on Rhodophyta Bangia sp. during austral summer 1996 (Fig. 8A). F. striatula and Licmophora spp. were significantly correlated with SS (Table 2B). The resuspension process would also make benthic diatoms available for benthic suspension feeders (Klöser et al. 1994, Ahn et al. 1993, 1997). Ahn et al. (1993) reported that benthic diatoms were abundant in the gut content of suspension-feeding bivalve Laternula elliptica. The tychoplanktonic species in intertidal and subtidal diatom communities seem to contribute

Table 3. Seasonal changes in monthly mean values of total microalgal carbon biomass (MCB), nanoflagellate carbon biomass $(\mathrm{CB})$, diatom $\mathrm{CB}$, nanoplanktonic MCB $(<20 \mu \mathrm{m})$, and microplanktonic MCB $(>20 \mu \mathrm{m})$

\begin{tabular}{|c|c|c|c|c|c|}
\hline & $\begin{array}{l}\text { Total } \\
\text { MCB }\end{array}$ & $\begin{array}{l}\text { Nano- } \\
\text { flagellates } \\
\text { CB }\end{array}$ & $\begin{array}{c}\text { Diatoms } \\
\text { CB }\end{array}$ & $\begin{array}{c}\text { Nano- } \\
\text { planktonic } \\
\text { MCB }\end{array}$ & $\begin{array}{l}\text { Micro- } \\
\text { planktonic } \\
\text { MCB }\end{array}$ \\
\hline January $(\mathrm{n}=21)$ & 20.07 & 9.50 & 10.58 & 12.31 & 7.76 \\
\hline February $(\mathrm{n}=29)$ & 23.18 & 7.29 & 15.89 & 9.62 & 13.56 \\
\hline $\operatorname{March}(\mathrm{n}=29)$ & 27.80 & 6.76 & 21.05 & 13.56 & 14.24 \\
\hline April $(\mathrm{n}=30)$ & 18.21 & 3.36 & 14.85 & 9.39 & 8.82 \\
\hline May (n = 27) & 15.23 & 2.32 & 12.91 & 10.16 & 5.07 \\
\hline June $(\mathrm{n}=19)$ & 4.17 & 2.68 & 1.49 & 2.91 & 1.26 \\
\hline July (n = 6) & 5.90 & 2.40 & 3.50 & 2.87 & 3.03 \\
\hline August $(\mathrm{n}=6)$ & 2.73 & 2.14 & 0.59 & 2.29 & 0.44 \\
\hline September $(n=17)$ & 16.50 & 2.62 & 13.88 & 9.98 & 6.52 \\
\hline October $(\mathrm{n}=29)$ & 40.87 & 5.35 & 35.52 & 13.77 & 27.10 \\
\hline November $(\mathrm{n}=30)$ & 109.28 & 12.43 & 96.61 & 25.94 & 83.34 \\
\hline December $(n=30)$ & 75.33 & 21.50 & 53.82 & 30.04 & 45.29 \\
\hline Integral & 29.94 & 6.53 & 23.39 & 11.90 & 18.03 \\
\hline
\end{tabular}




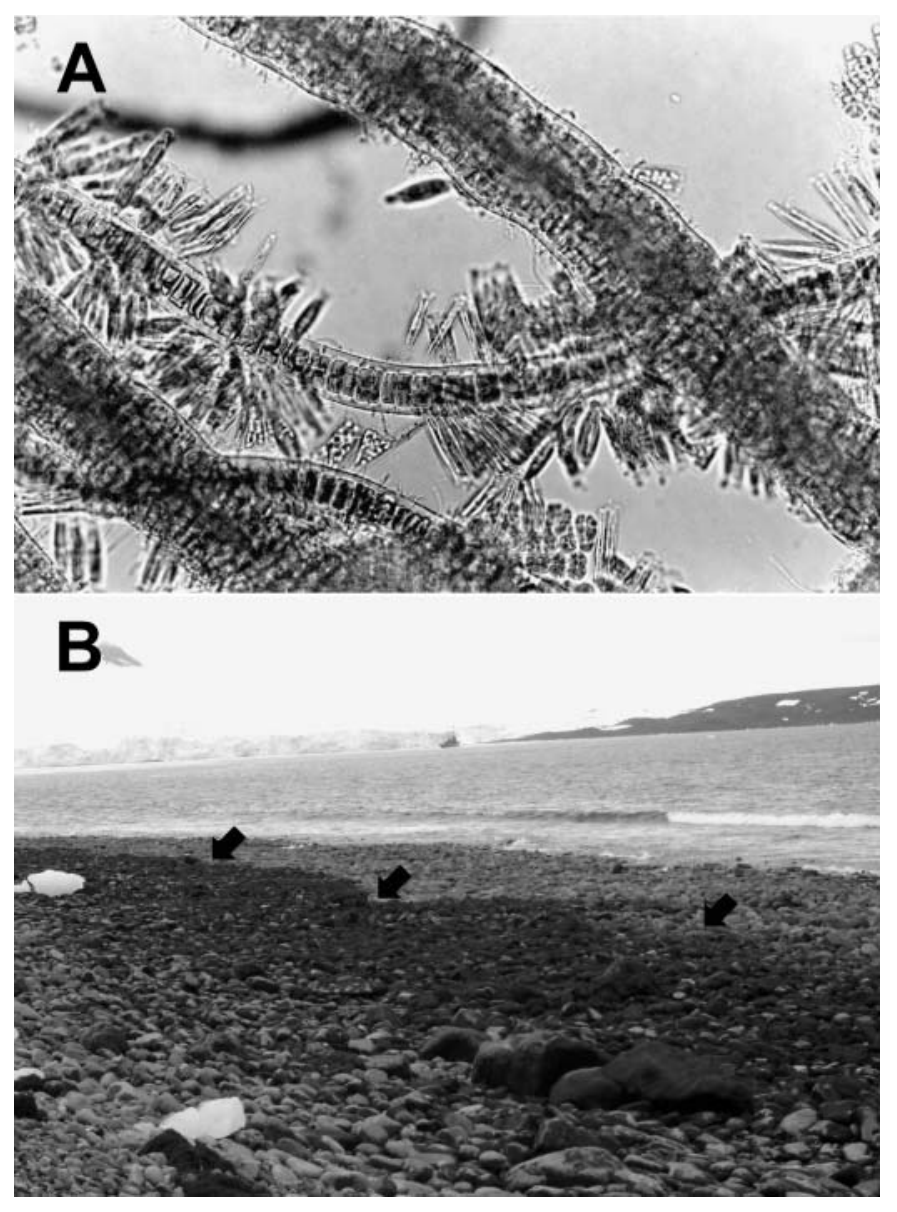

Fig. 8. (A) Microphotographs of benthic diatoms Fragilaria striatula and Licmophora belgicae attached on macrophyte Bangia sp. (B) Photographs of Bangia sp. and benthic diatom mat formed in intertidal zone. Note the boundary (see arrows) between the mat-forming area and grazed area by Nacella concina

substantially to the carbon source for the nearshore ecosystems of Marian Cove.

The benthic diatoms Fragilaria striatula and Licmophora belgicae increased abruptly during November and started to decrease in December (Fig. 6). This is probably due to grazing by the Antarctic limpet Nacella concinna, which is the most important grazer in the Antarctic shallow water (Walker 1972). N. concinna usually grazed filamentous algae Bangia sp. and benthic diatoms, and increased in abundance during summer near King Sejong Station (Dr. Dohong Kim pers. obs.; Fig. 8B), which might have caused the decrease of benthic-diatom abundance during summer.

The benthic diatoms Cocconeis spp. and Pseudogomphonema kamtschaticum were negatively correlated with salinity and positively correlated with air temperature and wind speed (Table $2 b$ ). These species are usually attached on subtidal macroalgae, Des- marestia mensiesii (Ahn et al. 1997, Klöser 1998). The increase of Cocconeis spp. and P. kamtschaticum during summer (low salinity and high air temperature) was probably due to favorable physicochemical conditions of summer, which are suitable for the growth of these diatoms. The positive correlation with wind speed suggests that Cocconeis. spp. and P. kamtschaticum were detached from the macroalgae and suspended into the water column during periods of strong wind.

The seasonal variation of Cocconeis spp. and Pseudogomphonema kamtschaticum also seems to have been influenced by substrate conditions (Fig. 6). The specific growth rate and photosynthetic capacities of the brown algae Desmarestia mensiesii increased during the late winter to spring and declined in summer (Gómez \& Wiencke 1997). The rapid growth rate of macroalgae and changes in $\mathrm{pH}$ at the thallus surface tend to prevent epiphytism (den Hartog 1972) and might have contributed to the paucity of the species during winter and spring. When the macroalgae grew slowly during summer, epiphytes would cover them rapidly, resulting in high abundance of Cocconeis spp. and P. kamtschaticum.

In conclusion, monitoring the seasonal variations of environmental factors and microalgal abundance in Marian Cove during 1996 has provided insights into the interactions of biological and environmental events. Air and water temperatures mainly affected the seasonal variation in nearshore microalgal abundance. The increase of microalgal abundance resulted in the depletion of nutrients. As Clarke \& Leakey (1996) pointed out, we need continuous and interdisciplinary yearround studies to understand the highly seasonal and complex nature of nearshore marine ecosystems.

\section{Succession of microalgae in the nearshore of King Sejong Station during 1996}

Diatoms accounted for the major carbon source in nearshore waters of King Sejong Station during 1996. Annual mean of total microalgal carbon biomass (MCB) was $29.9 \mu \mathrm{g} \mathrm{C} \mathrm{l}^{-1}$ (Table 3). Annual mean of diatom carbon biomass was $23.3 \mu \mathrm{gC} \mathrm{l}^{-1}$, which accounted for $77.9 \%$ of total MCB. Annual means of nanoplanktonic MCB and microplanktonic MCB were 11.9 and $18.0 \mathrm{\mu g} \mathrm{Cl}^{-1}$, respectively. This suggests that microplanktonic microalgae were more important as a carbon source than nanoplanktonic microalgae, although nanoplanktonic MCA $\left(1.26 \times 10^{6}\right.$ cells l$\left.^{-1}\right)$ was 
relatively higher than microplanktonic MCA $(5 \times$ $10^{4}$ cells $\mathrm{l}^{-1}$ ).

During summer (December through February), major carbon sources in January were the nanoflagellate Phaeocystis antarctica and other unidentified nanoplanktonic microalgae $\left(5.15 \mu \mathrm{g} \mathrm{Cl}^{-1}\right)$, whereas in December and February it was Licmophora belgicae (14.9 and $3.14 \mu \mathrm{g} \mathrm{C}^{-1}$, respectively). During fall (March through May), Navicula glaciei/perminuta was a major carbon source $\left(6.77,6.02\right.$, and $7.80 \mu \mathrm{g} \mathrm{C} \mathrm{l}^{-1}$, respectively). During winter, carbon mainly originated from $P$. antarctica and other unidentified nanoplanktonic microalgae (June: $0.99 \mu \mathrm{g} \mathrm{C}^{-1}$ ), Thalassiosira spp. (July: $1.33 \mu \mathrm{gC} \mathrm{l}^{-1}$ ), and $N$. glaciei/perminuta (August: $0.14 \mu \mathrm{gC} \mathrm{l}^{-1}$ ). Mean of total chl a was $<0.3 \mathrm{mg} \mathrm{m}^{-3}$ during winter. In spring, $N$. glaciei/perminuta (September: $7.32 \mu \mathrm{g} \mathrm{C}^{-1}$ ), Fragilaria striatula (October: $14.9 \mathrm{\mu g} \mathrm{C} \mathrm{l}^{-1}$ ), and Licmophora belgicae (November: $29.5 \mathrm{\mu g} \mathrm{C} \mathrm{l}^{-1}$ ) were major carbon sources.

Consequently, Navicula glaciei/perminuta was the major carbon source during late winter and early spring, when other microalgae were not yet in bloom. Subsequently tychoplanktonic benthic diatoms Fragilaria striatula and Licmophora belgicae started to increase in number and were abundant during summer. N. glaciei/perminuta was a major carbon source again during fall. Phaeocystis antarctica and other unidentified nanoplanktonic microalgae and Thalassiosira spp., which were abundant in winter, were probably introduced from outside of Maxwell Bay.

In conclusion, microalgae as the carbon source for benthic animals underwent changes seasonally with respect to abundance and species composition. Benthic diatoms were the major carbon source during summer and the cryophilic diatom Navicula glaciei/perminuta was the major source during spring, fall, and early winter. The planktonic species of Thalassiosira spp., Phaeocystis antarctica, and other unidentified nanoplanktonic phytoflagellates were major food sources for benthic animals during winter.

Acknowledgements. This work was supported by KORDI projects PP000102 \& PN0041201. We would like to thank Dr. K. H. Chung for nutrients data, Dr. B. Y. Lee for meteorological data. We are especially grateful to Dr. O. Holm-Hansen, Dr. W. O. Smith and anonymous reviewers for useful comments on the manuscript.

\section{LITERATURE CITED}

Ahn IY (1996) Feeding ecology of the Antarctic lamellibranch Laternula elliptica (Laternulidae) in Marian Cove and vicinity, King Goerge Island during one austral summer. Proceedings of the 6th SCAR Biology symposium, 1994, Venice. Cambridge University Press, Cambridge

Ahn IY, Kang JS, SH Kang (1993) Primary food sources for shallow-water benthic fauna in Marian Cove, King George Island during austral summer. Korean J Polar Res 4:67-72

Ahn IY, Chung H, Kang JS, Kang SH (1997) Diatom composition and biomass variability in nearshore waters of Maxwell Bay, Antarctica, during the 1992/1993 austral summer. Polar Biol 17:123-130

Arrigo KR, Robinson DH, Worthen DL, Dunbar RB, DiTullio GR, VanWoert M, Lizotte MP (1999) Phytoplankton community structure and the drawdown of nutrients and $\mathrm{CO}_{2}$ in the Southern Ocean. Science 283:365-367

Berkman PA, Marks DS, Shreve GP (1986) Winter sediment resuspension in McMurdo Sound, Antarctica and its ecological implications. Polar Biol 6:1-3

Booth BC (1993) Estimating cell concentration and biomass of autotrophic plankton using microscopy. In: Kemp PF, Sherr BF, Sherr EB, Cole JJ (eds) Handbook of methods in aquatic microbial ecology. Lewis Publishers, Boca Raton, p 199-205

Brandini FP, Rebello J (1994) Wind field effect on hydrography and Chlorophyll dynamics in the coastal pelagical of Admiralty Bay, King George Island, Antarctica. Antarct Sci 6:433-442

Buma AGJ, Gieskes WWC, Thomsen HA (1992) Abundance of Cryptophyceae and chlorophyll- $b$ containing organisms in the Weddell-Scotia Confluence area in the spring of 1988. Polar Biol 12:43-52

Chang KI, Jun HK, Park GT, Eo YS (1990) Oceanographic conditions of Maxwell Bay, King George Island, Antarctica (austral summer 1989). Korean J Polar Res 1:27-46

Chung H, Yang JS, Chung CS (1991) Seawater properties and macroalgal growth in littoral zone of Barton Peninsula, King George Island, Antarctica. Korean J Polar Res 2: $51-60$

Chung H, Oh YS, Lee IK, Kim DY (1994) Macroalgal vegetation of Maxwell Bay in King George Island, Antarctica (austral summer). Korean J Polar Res 9:47-58

Clarke A, Leakey RJG (1996) The seasonal cycle of phytoplankton, macronutrients, and the microbial community in a nearshore Antarctic marine ecosystem. Limnol Oceanogr 41:1281-1294

Clarke A, Holmes LJ, White MG (1988) The annual cycle of temperature, chlorophyll and major nutrients at Signy Island, South Orkney Islands, 1969-1982. Br Antarct Surv Bull 80:65-86

Dayton PK, Watson D, Palmisano A, Barry JP, Oliver JS, Rivera D (1986) Distribution patterns of benthic microalgal standing stock at McMurdo Sound, Antarctica. Polar Biol 6:207-213

Demers S, Therriault JC, Bourget E, Bah A (1987) Resuspension in the shallow subslittoral zone of a macrotidal estuarine environment: wind influence. Limnol Oceanogr 32: $327-339$

den Hartog C (1972) Substratum: multicellular plants. In: Kinne O (ed) Marine ecology, Vol 1. John Wiley, New York, p 1277-1289

Domanov MM, Lipski M (1990) Annual cycle of chlorophyll a and primary production of phytoplankton in Admiralty Bay (Antarctica). Pol Arch Hydrobiol 37:471-478

Dunbar RB, Leventer AR, Stockton WL (1989) Biogenic sedimentation in McMurdo Sound, Antarctica. Mar Geol 85: $155-179$

El-Sayed S (1984) Productivity of the Antarctic waters-a reappraisal. In: Holm-Hansen O, Bolis L, Gilles R (eds) Lecture notes on coastal and estuarine studies, No. 8, Marine Phytoplankton and Productivity. Springer-Verlag, Berlin, p 19-43 
Everitt DA, Thomas DP (1986) Observations of seasonal changes in diatoms at inshore localities near Davis Station, east Antarctica. Hydrobiologia 139:3-12

Fiala M, Oriol L (1990) Light-temperature interactions on the growth of Antarctic diatoms. Polar Biol 10:629-636

Fukuchi M, Tanimura A, Ohtsuka H (1985) Marine biological and oceanographical investigations in Lützow-Holm Bay, Antarctica. In: Siegfried WR, Condy PR, Laws RM (eds) Antarctic nutrient cycles and food webs. Springer-Verlag, Berlin, p 52-59

Gilbert NS (1991) Primary production by benthic microalgae in nearshore marine sediments of Signy Island, Antarctica. Polar Biol 11:339-346

Gómez I, Wiencke C (1997) Seasonal growth and photosynthetic performance of the Antarctic macroalga Desmarestia menziesii (Phaeophyceae) cultured under fluctuating Antarctic daylengths. Bot Acta 110:25-31

Grossi SM, Kottneier ST, Moe RL, Taylor GT, Sullivan CW (1987) Sea ice microbial communities. VI. Growth and primary production in bottom ice under graded snow cover. Mar Ecol Prog Ser 35:153-164

Heywood RB, Whitaker TM (1984) The Antarctic marine flora. In: Laws RM (ed) Antarctic ecosystem. Vol. 2. Academic Press, New York

Horne AJ, Fogg GE, Eagle DJ (1969) Studies in situ of the primary production of an area of inshore Antarctic Sea. J Mar Biol Assoc UK 49:393-405

Horner RA, Schrader GC (1982) Relative contributions of ice algae, phytoplankton and benthic microalgae to primary production in the nearshore regions of the Beaufort Sea. Arctic 35:485-503

Kang JS, Kang SH, Lee JH (1999) Cryophilic diatoms Navicula glaciei and N. perminuta in Antarctic coastal environment. I. Morphology and ecology. Algae 14: 169-179

Kang SH (1993) Slide making with HPMA (2-hydroxypropyl methacrylate). In: Workshop on Antarctic glacial marine and biogenic sedimentation notes for a shortcourse. Part 2. Biogenic sedimentation. Sedimentology Research Laboratory Contribution, $\mathrm{p} 139-140$

Kang SH, Kang JS (1997) Seasonal variation of environmental factors and nearshore microalgae in Marian Cove, King George Island, Antarctica during 1996: preliminary study for long-term monitoring. In: Environmental monitoring on human impacts at the King Sejong Station, KORDI, p 57-112

Kang SH, Lee S (1995) Antarctic phytoplankton assemblage in the western Bransfield Strait region, February, 1993: composition, biomass, and mesoscale distributions. Mar Ecol Prog Ser 129:153-167

Kang SH, Fryxell GA, Roelke DL (1993) Fragilariopsis cylindrus compared with other species of the diatom family Bacillariaceae in Antarctic marginal ice-edge zones. Nova Hedwigia 106:335-352

Kang SH, Kang JS, Chung KH, Lee MY, Lee BY, Chung H, Kim Y, Kim DY (1997) Seasonal variation of nearshore Antarctic microalgae and environmental factors in Marian Cove, King George Island, 1996. Korean J Polar Res 8: $9-27$

Kang SH, Kang JS, Lee S, Chung KH, Kim D, Park MG (2001)

Editorial responsibility: Osmund Holm-Hansen (Contributing Editor), La Jolla, California, USA
Antarctic phytoplankton assemblages in the marginal ice zone of the northwestern Weddell Sea. J Plankton Res 23: $333-352$

Klöser H (1998) Habitats and distribution patterns of benthic diatoms in Potter Cove (King George Island, Antarctica) and its vicinity. Rep Polar Res 299:95-105

Klöser H, Ferreyra G, Schloss I, Mercuri G, Laturnus F, Curtosi A (1994) Hydrography of Potter Cove, a small fjordlike inlet on King George Island (South Shetlands). Estuar Coast Shelf Sci 38:523-537

Krebs WN (1983) Ecology of neritic marine diatoms, Arthur Harbor, Antarctica. Micropaleontology 29:267-297

Ligowski R (1983) Phytoplankton of the Olaf Prydz Bay (Indian Ocean, East Antarctica) in February 1969. Pol Polar Res 4:21-32

McConville MJ, Citchell C, Wetherbee R (1985) Patterns of carbon assimilation in a microalgal community from annual sea ice, east Antarctica. Polar Biol 4:135-141

Moline MA, Claustre H, Frazer TK, Grzymski J, Schofield O, Vernet M (2000) Changes in phytoplankton assemblages along the Antarctic Peninsula and potential implications for the Antarctic food web. In: Davison W, HowardWilliams C, Broady P (eds) Antarctic ecosystems: models for wider ecological understanding. Caxton Press, Christchurch, New Zealand, p 263-272

Mura MP, Agustí S (1998) Increased frequency of dividing cells of a phototrophic species of Cryptophyceae at a frontal structure off the Antarctic Peninsula. J Plankton Res 20:2357-2367

Palmisano AC, Sullivan CW (1983) Sea ice microbial communities (SIMCO). 1. Distribution, abundance, and primary production of ice microalgae in McMurdo Sound. 1980. Polar Biol 2:171-177

Palmisano AC, Lizotte MP, Smith GA, Nichols PD, White DC, Sullivan CW (1988) Changes in photosynthetic carbon assimilation in Antarctic sea ice diatom during a spring bloom: variation in synthesis of lipid classes. J Exp Mar Biol Ecol 116:1-13

Parsons TR, Maita Y, Lalli CM (1984) A manual of chemical and biological methods for seawater analysis. Pergamon Press, Oxford

Perrin RA, Lu P, Marchant HJ (1987) Seasonal variation in marine phytoplankton and ice algae at a shallow Antarctic coastal site. Hydrobiologia 146:33-46

Picken GB (1985) Marine habitats. In: Bonner WN, Walton DWH (eds) Key environments-Antarctica. Pergamon Press, Oxford, p 154-172

Smayda TJ (1978) From phytoplankton to biomass. In: Sournia A (ed) Monographs on oceanic methodology 6. Phytoplankton Manual. UNESCO, Paris, p 273-279

Tokarczyk R (1986) Annual cycle of chlorophyll a in Admiralty Bay, 1981-1982 (King George, South Shetlands). Pol Arch Hydrobiol 33:177-188

Walker AJM (1972) Introduction to the ecology or the Antarctic limpet Patinigera polaris (Hombron and Jacquinot) at Signy Island, South Orkeney Island. Br Antarct Surv 28:49-60

Whitaker TM (1982) Primary production of phytoplankton off Signy Island, South Orkneys, the Antarctic. Proc R Soc Lond Ser B 214:169-189

Submitted: November 28, 2000; Accepted: June 18, 2001

Proofs received from author(s): March 4, 2002 